\title{
The Inception Of Ethical Banking: An Imperative Transformation In Post-Revolution Egypt
}

Nirmala Dorasamy, Durban University of Technology, South Africa Monal A. Abdel-Baki, Durban University of Technology, South Africa

\begin{abstract}
While the Egyptian Revolution has initiated democratic transformation, the economy remains vulnerable to shocks that are apt to exacerbate unemployment, inequity, and poverty - the prime triggers of the popular uprising. Stability hinges on the newly elected government's ability to accelerate macroeconomic growth, create jobs, and alleviate poverty. Prior to the popular unrest, the Egyptian banking sector was principally focused on financial return, and Egyptian regulators were mainly concerned with bank soundness. While there has been a paradigm shift in bank customers' perception of banks as needing to have an intrinsic ethical responsibility, ethical banking is still in its infancy stage in the Egyptian banking sector. This research aims to bridge the gap between the newly developed perceptions of Egyptian savers/borrowers on the one hand and the conduct of bankers on the other hand. To this avail, we introduce a two-stage model where the value creation of banks is not solely confined to pure financial value - but the human, social, and environmental demands of all stakeholders are integrated. In the first stage, instead of adopting mainstream ethics and sustainability indexes, we administer a field survey in order to develop a stakeholder-centric view of the requisites of (1) ethical banking principles, (2) lending policies with human, socially, and ecologically responsible criteria, (3) ethical screening, (4) risk minimization, and (5) the maximization of financial returns. Subsequent to building the allinclusive Ethical Banking Index (EBI), the second stage of the model gauges the performance of Egyptian banks. The EBI is not only applicable to Egypt, but could also prove useful to nations encountering similar socioeconomic woes.
\end{abstract}

Keywords: Ethical Banking; Economic Development

\section{INTRODUCTION}

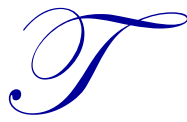

he bank reform efforts enacted by the Central Bank of Egypt (CBE) since 2004 rendered Egyptian banks consolidated, sounder, and capable of providing diversified services. Amid the global meltdown, the adequately capitalized Egyptian banking sector was able to endure the financial crisis commendably. This resilience has raised expectations and dependence on the reformed banking sector - savers entrust the solid banking sector with their deposits, central bankers count on the deepened banking industry to mobilize more savings, policymakers expect the prudently managed banks to deliver job-generating lending, and the fiscal agent resorts to the reinforced banks to finance the escalating public debt.

The Triple-F Crisis - finance, food, and fuel - has further underscored the role of Egyptian banks in poverty alleviation. The main goals of the Bank Reform Plan (BRP), which was interrupted by the 2011 Egyptian revolution, are to enhance the role of bank credit in increasing the levels of financial inclusion, deepen banking sector penetration, generate jobs, and reshape macroeconomic growth dynamics. The BRP gave immense incentives to banks to lend responsibly, exempting loans to small and medium enterprises (SMEs) from the legal reserve ratio, but regulatory frameworks have a much lower impact on inclusive finance and societal well-being in comparison to institutional initiatives. Unless the banks' shareholders and Board of Directors (BoD) direct bank management 
toward responsible and ethical lending, the banking sector will not be capable of fulfilling its vital task of helping the economy recover and sustain its growth (World Savings Banks Institute, 2011).

The politically turbulent transition period that superceded the 2011 Egyptian revolution has impaired macroeconomic growth, increased unemployment, and swelled national debt. Ironically, instead of fulfilling the demands that were at the heart of the uprising, the political instability has exacerbated poverty and unemployemnt. Under the turbulent political scene and the economic bleak outlook, funds have traveled out of financial instruments into bank deposits. While bank deposits increased by 21.2 percent from January 2010 until March 2013 (Central Bank of Egypt, 2013), the Egyptian stock market capitalization plummeted from 37.7 to 21.2 for the same period (The World Bank, 2013). Hence, the dependence on the Egyptian banking sector as the main credit provider has increased. To survive the economic shock exerted by the revolution, it is imperative for banks to take an active role in fulfilling the combined challenging responsibilities and societal expectations at this crucial time in Egyptian history.

This paper attempts to build an ethical banking value creation index that is not solely confined to pure financial value, but also integrates the human, social, and environmental responsible banking aspects. Introducing the composite Ethical Banking Index (EBI) is aimed at building an indicator reflecting the level of responsible behaviour within banking institutions.

\section{LITERATURE REVIEW - SOCIALLY RESPONSIBLE AND ETHICAL BANKING}

As financial deregulation increasingly shaped the decision-making paradigms in many economies round the world since the 80's, its opponents considered it as a trigger factor for high reward risk-taking activities that serve the interests of shareholders at the expense of the society at large (Green, 1989). The overdependence on the free market mechanism and the less-than-prudent regulatory supervision allowed bankers to deviate from their prime role of serving their communities toward engaging in speculative transactions (Lynch, 1991). In reaction to the ensuing risks, pundits advocated the stringent regulation of the opaque financial instruments and reckless bank loan policies (Hogan \& Sharpe, 1989), but empirical studies revealed an paradoxical result - instead of mitigating risk exposure, regulatory capital and stern supervision raised the cost for banks, making them take even higher risks (Shrieves \& Dahl, 1992; Jacques \& Nigro, 1997). Moreover, banks engaged in regulatory arbitrage in order to reduce costs of raising capital (Jones, 2000).

Reinforcing the one-size-fits-all Basel Accord, capital adequacy regulatory framework was considered as inefficient in shielding the banking sector from risks (Stiglitz, 2003). In fact, bankers contest that Basel III, which regulators hail as "the most comprehensive regulatory package for banks" (Westlake, 2013), tolls the death knell to sustainable growth and inclusive socioeconomic development (Institute of International Finance, 2011). As much as private bankers oppose the stringency of the new capital and liquidity requirements, they do not propose alternative models for banks (Whitehead, 2012).

Financial regulation is undoubtedly beneficial in reining in the risk appetite, but it does not suffice (Barth et al., 2004). Banks are expected to practice "mandatory" ethical operations to alleviate societal problems and to enhance the quality of life of all stakeholders (Jamali, 2007). This does not imply that altruistic social responsibility should compromise banks' financial performance, but the reconciliation of social and economic benefits require that the shareholder model must be replaced by the "dual bottom-line" stakeholder model (Ayadi et al., 2009). In order to build their "reputational capital," banks have to act as good corporate citizens who contribute to socioeconomic development and fulfill the demand for ethical principles from customers, investors, and the society at large (Nwankwo, 1991).

Banks can identify activities that benefit the business and society through long-term investments, which offer prospects of greater creditability and added value (von Mettenheim \& Butzbach, 2012). The first premise that the recent economic global turmoil has established is that the most vandalized economies were the ones that tolerated an excessive growth of their banking sectors to substantially outweigh the size of their economies (Arcand et al., 2012). In cases where economies lean on a disproportionately large financial sector, there will come a time when this growth will not only jeopardize macroeconomic performance, but will harm the society at large (Claessens \& Laeven, 2005). If the banking sector grows excessively large beyond a specific threshold, it is apt to 
reallocate resources toward speculative and risky transactions (Bini Smaghi, 2010), leading ultimately to costly crises (Beck et al., 2012). For this reason, the size of the banking sector should match and serve the economic needs of the nation and the financial demands of households and investors (Beck et al., 2008).

Hence, the banking sector urgently requires a massive cultural change to serve its stakeholders per se and the society at large through responsible banking practices that valorize financial inclusion and fair lending (Schoenmaker \& Werkhoven, 2012). The aims of ethical banking extend beyond economic benefits to embrace social objectives in terms of the triple bottom line - people, planet, and profit (Tse, 2011). Ethical banks provide a high level of transparency and more detailed information to their stakeholders with regard to where money has been lent. To establish an ethical relationship with their stakeholders, banks are obliged to display accountability in terms of integrity, responsibility, and affinity (San-Jose et al., 2011). It may be true that most banks have adopted edicts of Corporate Social Responsibility (CSR), but the collapse of the inflated banking sectors in some European nations, which were actively reporting CSR activities and Basel II compliance, is vivid proof that CSR is largely mistaken for strategic philanthropy and branding (Sigurthorsson, 2012). Ironically, in its quest to ensure that banks hold adequate levels of capital and liquidity, the Basel Committee for Banking Supervision (BCBS) does not pay much heed to how the risk-weighted-asset (RWA) method of calculation inherently circumvents banks from extending loans to the "risk-exposed" SMEs. If job creation and GDP growth are among its prime priorities, then the BCBS needs to give these socially responsible loans - that are a prime source of job creation - differential and more favourable treatment (IIF, 2011).

Furthermore, the very edicts of responsible banking are a rare practice among banks in developing and emerging countries (Hu \& Scholtens, 2012). A study by Wahba (2008) concluded that investors in the Egyption context are short-term oriented and any of their socially responsible investments are merely for the sake of tokenism rather than for genuine long-term interests. Especially in the wake of the rising waves of nationalism and democratic transition in emerging market economies, well-informed stakeholders are increasingly demanding clear and hard facts about the social and environmental performance of banks, since banking is regarded as too important and sensitive to be left to bankers alone (Archua, 2012). Therefore, a cultural change is required so that banks are not held guilty of superficially applying CSR activities (Rahaman et al., 2004). A study by Pomering and Dolnicar (2006) found that CSR initiatives, which strongly favour customers, elicit superior attitudinal responses, while McDonald and Rundle-Thiele (2008) recommend the identification of a hierarchy of customer-preferred CSR initiatives to benefit the customer, the community, and the society.

Building a fair and transparent partnership between the customer and all stakeholders - based on long-term respect and confidence - is the cornerstone of stakeholder value ethos (SVE) of ethical banking (Ayadi et al., 2009). The central issues that banking institutions need to address are the ethical impact of their investments on the environment, society, and corporate governance (ESG) integration (Freshfields Bruckhaus Deringer, 2005). Opponents of ethical banking claim that it restricts and crowds out the profitable investment opportunities, making such SVE and ethical banking models unprofitable and unsustainable (Hong \& Kacperczyk, 2009). Advocates of socially responsible strategies argue that bankers do not impose a significant performance penalty since they assign only a portion of their portfolio to ESG assets and readily achieve comparable risk-adjusted returns (Le Maux \& Le Saout, 2004).

Hence, as much as this requires a major reform of the present culture and the current banking model, it is imperative to strike the right balance between generating profits, meeting the societal needs, and providing the consumer and corporate sectors with financial support; in other words, the model should be expanded from ESG to FESG to include the various financial dimensions (Jemli \& Chtourou, 2010). The financial dimension is two-fold: (1) to maximize profits by building optimized asset portfolios and (2) to include an ESG ethical dimension that takes into consideration country, industry, credit, liquidity, and interest rate risks (Kurtz \& diBartolomeo, 2011). This approach will surely have a stabilizing effect on financial markets since inclusive finance has a long-term perspective without disrupting the short-term maximization of goals (World Savings Banks Institute, 2010).

As much as various business models have been proposed to serve this imperative banking mission shift, less effort is exerted to gauge the extent to which banks balance between financial and social goals. Many financial institutions have developed standard measurement scales of sustainably, CSR, and social inclusion. The most famous examples are Dow Jones Sustainability Index, MSCI ESG Index, FTSE4Good Index Series, and ESI 
Sustainability Index that use a number of variables to detect the responsibility of lenders with regard to ethical lending and asset management decisions. However, these are used to benchmark and rate companies' social responsibility performance from the perspective of stock market investors solely.

The literature is rich in measuring bank service quality (Abdullah et al., 2011), but ethical banking measures are quite modest and simply rank performance in accordance with a given set of metrics of responsible banking behaviour (Cowton, 1998). With the outbreak of the Global Financial Crisis (GFC), the public, regulators, and bankers' demands for responsible banking were revived urging both scholars and practitioners to construct sustainability and ethical banking indexes. San-Jose and Retolaza (2008) developed a Radical Affinity Index that gauges the level of ethical banking affinity in accordance with the banks' final usage of funds. Using a composite index of 27 sustainability variables, Eccles et al. (2011) compare a sample of 90 high sustainability firms against 90 low sustainability firms. The results reveal that firms that had been adopting socially and environmentally responsible policies for over ten years outperform newcomers in terms of profitability and stock market performance, albeit that this competitive advantage is observed in the long-run. El Ghoul et al. (2011) develop an index comprising multiple variables, such as responsible employee relations, environmental policies, and ethical products. Their findings show that firms scoring higher social responsibility have access to cheaper equity financing. Nagy et al. (2013) use the MSCI ESG Index and confirm that firms displaying ESG policies are seen to reap higher revenue and capital gains during periods of economic slump.

As helpful as these indexes may be, three observations are worth mentioning. First, most of the abovementioned indexes are quite novel and have been constructed in response to the GFC. The deviation of banking and financial institutions from performing their core function toward non-banking and complex financial transactions begged for an immediate voluntary engagement in ethical transactions. Second, as the need arose for building an index that measures the level of progress of banks with regard to responsible behaviour, pundits built such indexes based on subjective assumptions rather than on the true expectations of stakeholders. A third concern is that most of the indexes that have been built so far do not address the special circumstances of emerging market economies that are endeavouring to transition toward democratic rule, where the banking sector has to serve more important human and economic development roles in comparison to developed nations. As such, the literature is in dire need for building an ethical banking performance index from the perspective of the emerging market society that is actively striving to be an active agent in the democratic transformation process.

\section{THE EMPIRICAL MODEL}

To understand whether the banking sector is showing evidence of the discharge of its societal obligations and responsibilities, a two-stage model is constructed. In the first stage, a field survey is administered to comprehend the true expectations and demands of the various shareholders from the banking sector. Based on the results of the survey, a composite stakeholder-centric ethical banking index (EBI) is constructed. The EBI is used in the second stage of the model to test the hypothesis whether the overall performance of ethical banks (as measured by the EBI score) leads to higher results.

\section{First Stage of the Model - The Field Survey}

Since the society authorizes the legitimate and continued existence of banks, the relationship between individuals, banks, and society can be viewed as a social contract (Farook et al., 2001). This implies that banks have to approach their stakeholders in order to legitimize their existence. The first stage of the model aims to define this social contract. A field survey was administered during the period September 2012 until December 2012, whereby a total of 3,250 questionnaires were equally distributed among three categories of bank stakeholders - customers, employees, and managers of 114 bank branches in ten different governorates. The response rate was surprisingly high - at $66 \%$ yielding 2,145 responses. The questionnaire comprised of 20 Likert-scale questions and five openended questions.

A weighted index of ethical banking practices is constructed in accordance with customer preferences to measure the level of identified policies that customers require their banks to commit to. As a means of cutting down on excessive result overload, a number of mechanisms, that the customers require their banks to adopt, are inserted and calculated as a percentage of seven broader ethical banking mechanisms. (Details of these seven categories are 
available upon request from the authors.) Table 1 summarizes the metrics and weights of the Ethical Banking Index, in accordance with the demand of the stakeholders.

Table 1: Weighted Ethical Banking Index

\begin{tabular}{|l|c|}
\hline \multicolumn{1}{|c|}{ Ethical Banking Mechanisms } & Weight \\
\hline $\mathrm{M}_{1}$ : Place bank's assets in projects with positive social-added value & 0.21 \\
\hline $\mathrm{M}_{2}$ : Disclose information about type of credit, especially for large loans & 0.29 \\
\hline $\mathrm{M}_{3}$ : Make cheap loans to SMEs and entrepreneurial startups & 0.22 \\
\hline $\begin{array}{l}\mathrm{M}_{4} \text { : Develop alternative guarantee systems to promote investments in social projects that do not provide } \\
\text { conventional guarantees }\end{array}$ & 0.17 \\
\hline $\mathrm{M}_{5}$ : Engage board of directors in reviewing ethical performance of banks & 0.06 \\
\hline $\mathrm{M}_{6}$ : Base top management incentives on ethical performance & 0.04 \\
\hline $\mathrm{M}_{7}$ : Prohibit lending to environmentally harmful projects & 0.01 \\
\hline
\end{tabular}

\section{Second Stage of the Model - The Field Survey}

The data are collected from 1998 to 2012 - the period subsequent to the 1997 banking crisis. This period also includes important changes in the banking sector; namely, the dual Bank Reform Plans of 2004-2009 and 20092012 , the Triple-F crisis, and the political uprising of 2011. The macroeconomic data are collected from the databases of the Central Bank of Egypt, the Ministry of Finance, Central Agency for Public Mobilization and Statistics (CAPMAS), the World Bank (WB), and the International Monetary Fund (IMF).

As for the level of compliance with responsible banking activities, a combination of primary and secondary sources is utilized. The annual reports and websites of banks are used to trace ethical practices. Then, 48 interviews were conducted with senior bank managers to validate the extent of adoption of these policies. Due to the small size of the banking sector, the study covers the entire 39 banks operating in Egypt. Table 2 reports the mean EBI scores of each type of Egyptian bank.

Table 2: Mean EBI Scores of Egyptian Banks

\begin{tabular}{|l|c|}
\hline \multicolumn{1}{|c|}{ Bank Type } & Mean EBI Score \\
\hline State-Owned Specialized Banks & 0.772 \\
\hline State-Owned Commercial Banks & 0.517 \\
\hline Private Domestic Banks & 0.451 \\
\hline Foreign Banks & 0.115 \\
\hline
\end{tabular}

The banks are grouped into two categories as shown in Table 3 - highly compliant and low-compliant with EBI. Almost half Egyptian banks have, on the average, adopted at least $55 \%$ of responsible banking policies, while the other half adopted as low as $11 \%$ of these mechanisms. The results suggest that specialized public banks followed by commercial public banks - are the most responsible lenders and readily disclose activities. Also, banks included in the High EBI group have developed a distinct governance structure, and assign to the Board of Directors and top management, remuneration in accordance with ethical practices. Finally, all Egyptian banks pay very little attention to the environmental impact of their practices.

Table 3: Sampling of Egyptian Banks

\begin{tabular}{|l|c|c|c|}
\hline \multicolumn{1}{|c|}{ Category } & Total Number of Banks & High EBI Score & Low EBI Score \\
\hline State-Owned Specialized Banks & 3 & 3 & 0 \\
\hline State-Owned Commercial Banks & 3 & 2 & 1 \\
\hline Private Domestic Banks & 26 & 13 & 13 \\
\hline Foreign Banks & 7 & 2 & 5 \\
\hline Total & 39 & 20 & 19 \\
\hline
\end{tabular}

Each of the banks in the first group is matched with a bank that scores low on responsible policies. Normal matching cannot be employed in this case due to the lack of significant overlap, which carries the risk of introducing substantial errors. A better technique is to use propensity score matching (PSM) to produce a group of control banks. The PSM is run for three consecutive years (2004, 2005, and 2006) to ensure that the results are not sensitive to any specific year. The reason for selecting these years is that this is the period when substantial bank reforms and 
corporate governance guidelines were adopted by the Central Bank of Egypt. The size of the banks is controlled by calculating total assets at the end of 2012 since bank assets change from year to year. Table 4 reports the bank characteristics, where the covariates that are used are:

- $\quad$ ROE: net income/equity

- $\quad$ ROA: net income + after tax net interest expenses/total assets

- $\quad \log$ assets: proxy of the size of the bank

- $\quad$ NPL/total assets

- $\quad$ BtM ratio: book value of the share/market price of the share

- leverage ratio: total liabilities/total assets

Table 4: Bank Characteristics

\begin{tabular}{|l|c|c|c|c|c|c|c|c|c|c|c|c|}
\hline & \multicolumn{2}{|c|}{ ROE } & \multicolumn{2}{c|}{ ROA } & \multicolumn{2}{c|}{ Log Assets } & \multicolumn{2}{c|}{ NPL } & \multicolumn{3}{c|}{ BtM Ratio } & \multicolumn{2}{c|}{ Leverage } \\
\hline & $\bar{x}$ & $\sigma$ & $\bar{x}$ & $\sigma$ & $\bar{x}$ & $\sigma$ & $\bar{x}$ & $\sigma$ & $\bar{x}$ & $\sigma$ & $\bar{x}$ & $\sigma$ \\
\hline Favourable & 13.8 & 11.2 & 1.0 & 0.9 & 3.7 & 1.7 & 4.1 & 5.6 & 0.43 & 0.31 & 0.57 & 0.55 \\
\hline Poor & 10.2 & 8.4 & 0.8 & 0.7 & 2.2 & 3.1 & 17.8 & 19.2 & 0.57 & 0.67 & 0.79 & 0.59 \\
\hline$p$-value & \multicolumn{2}{|c|}{0.87} & \multicolumn{2}{|c|}{0.89} & \multicolumn{2}{c|}{0.91} & \multicolumn{2}{c|}{0.92} & \multicolumn{2}{c|}{0.881} & 0.712 \\
\hline
\end{tabular}

$p$-value: test of equality of $\bar{x}$ across the two groups

\section{RESULTS}

The multivariate analysis is performed to measure the level of bank engagement in each of the seven ethical banking mechanisms. The dependent variables $\left(\mathrm{M}_{1}-\mathrm{M}_{7}\right)$ are defined in Table 1 . These are tested against accounting and performance ratios (as an average for the period of the study) and reported in Table 5.

The first determinant of the stakeholder motivated EBI is the engagement of the bank in activities that have a societal impact. These range from job-generating loans and investments to lending to importers of economically productive projects, such as wheat growers or producers of machinery and its spare parts. The effects are substantially positive in generating profits and increasing the growth potential of banks, but this mechanism has an insignificant impact on the settlement of non-performing loans.

Disclosing information about maturities, amounts, and beneficiaries of loans has a substantial effect on bank performance, especially for reducing bad debts and condensing the extent to which banks are leveraged.

A related demand that is assigned significant importance by the stakeholders is the portion of loans made to small and medium enterprises. Consistent with the previous results, loaning SMEs cheaply has very positive effects on profitability and growth potential. Also, surprisingly, the NPL rate is healthy. This deserves some further explanation; however, unlike regular loans, most banks involved in this lending activity are closely engaged with small borrowers in terms of providing guidance, training their personnel, and marketing their products through a large number of outlets.

This leads to the following ethical banking mechanism; namely, providing non-conventional guarantees of repayment of loans. The results show that profitability and asset growth increase in banks providing these guarantees. These guarantees also reduce the leverage of banks since these banks manage to improve the credit score of their borrowers in less than three years.

High EBI-scoring banks have a higher level of involvement of board members and directors. Involving directors in ethical mechanisms of the banks is found to increase profitability, but not growth opportunities. It also has a significant effect on reducing non-performing loans and leverage of the banks.

Similarly, tying remuneration to ethical practices has a low impact on profitability growth opportunities. It may have some effect on reducing NPLs, but hardly on leverage.

Finally, there appears to be very little awareness and, hence, quite negligible impact of the environmental impact of banking operations. 
Table 5: Value-Weighted Multivariate Analysis of Ethical Mechanisms in Egyptian Banks

\begin{tabular}{|c|c|c|c|c|c|c|c|c|c|c|c|c|c|c|}
\hline & \multicolumn{2}{|c|}{$\mathbf{M}_{1}$} & \multicolumn{2}{|c|}{$\mathbf{M}_{2}$} & \multicolumn{2}{|c|}{$\mathbf{M}_{3}$} & \multicolumn{2}{|c|}{$\mathbf{M}_{4}$} & \multicolumn{2}{|c|}{$\mathbf{M}_{5}$} & \multicolumn{2}{|c|}{$\mathbf{M}_{6}$} & \multicolumn{2}{|c|}{$\mathbf{M}_{7}$} \\
\hline & & $p$-value & & $p$-value & & $p$-value & & $p$-value & & $p$-value & & $p$-value & & $p$-value \\
\hline Intercept & 2.277 & 0.000 & 0.222 & 0.004 & 1.896 & $<0.0001$ & 0.896 & 0.0001 & -0.411 & 0.167 & 0.227 & 0.116 & 1.897 & 0.000 \\
\hline $\begin{array}{l}\text { High } \\
\text { EBI }\end{array}$ & 2.891 & 0.001 & 0.145 & 0.008 & 1. 177 & 0.014 & 0.966 & 0.014 & 0.281 & 0.070 & 0.115 & 0.154 & 0.029 & 0.916 \\
\hline ROE & 2.171 & 0.000 & 0.087 & 0.003 & 1.971 & 0.000 & 1.991 & 0.000 & 0.112 & 0.221 & 0.002 & 0.631 & 0.016 & 0.0001 \\
\hline $\mathrm{ROA}$ & 1.197 & $<0.0001$ & 0.037 & 0.055 & 0.917 & 0.000 & 1.238 & $<0.0001$ & 0.128 & 0.192 & 0.007 & 0.572 & 0.0092 & $<0.0001$ \\
\hline Assets & 2.231 & 0.0002 & 0.087 & 0.003 & 2.031 & 0.002 & 0.911 & 0.000 & 0.072 & 0.012 & 0.037 & 0.015 & -0.0036 & 0.0012 \\
\hline NPL & -0.114 & 0.012 & -0.006 & 0.569 & -1.002 & 0.001 & -1.221 & 0.001 & -0.212 & 0.115 & -0.161 & $<0.0001$ & 0.0016 & 0.0001 \\
\hline BtM & -0.002 & 0.087 & 0.59 & 0.435 & -0.003 & 0.003 & 0.038 & 0.070 & 0.013 & 0.012 & 0.001 & 0.025 & 0.004 & 0.001 \\
\hline Leverage & -1.115 & 0.000 & -0.012 & 0.332 & -0.1185 & 0.001 & -0.054 & 0.093 & -0.109 & 0.014 & -0.003 & 0.001 & -0.0016 & 0.0001 \\
\hline Adj $R^{2}$ & \multicolumn{2}{|c|}{$28.2 \%$} & \multicolumn{2}{|c|}{$81.3 \%$} & \multicolumn{2}{|c|}{$17.4 \%$} & \multicolumn{2}{|c|}{$33.4 \%$} & \multicolumn{2}{|c|}{$54.2 \%$} & & & \multicolumn{2}{|c|}{$10.4 \%$} \\
\hline
\end{tabular}

EBI takes the value of 1 if the bank belongs to the first group of high EBI scores. 


\section{CONCLUDING REMARKS}

Prior to its popular revolution, Egypt was steadily moving toward becoming a large financial centre in North Africa. The consolidation and reform of Egyptian banks has led to increased competition in the banking system as well as the introduction of more innovative and sophisticated banking products (Tantawi \& Youssef, 2012). This has developed and changed the core importance of banks, especially in view of the social, economic, and political dilemmas which affected trust and confidence in many institutions in Egypt. The revolution has left Egypt ever so more suffering from widespread poverty, income inequality, corruption, and social exclusion. Hence, in the new era, the society requires that Egyptian banks become an important agent of change and economic development. In a study conducted by Hu and Scholtens (2012), it was reported that banks in Egypt have the lowest socially conscience and CSR performance, which obviously affects the trust which customers want from their banks. Nevertheless, their study does not go into differential analysis of banks and reports only aggregate findings. To examine the level of validity of their finding, this research studies the degree to which Egyptian banks are converging toward attaining their newly required socially responsible behaviour.

The results of the current study show that the high-scoring EBI group of banks report, overall, better accounting results and financial performance. This finding suggests that banks could adopt ethical and responsible mechanisms and policies without sacrificing shareholders' wealth. This group of banks is indeed more tilted toward the stakeholder model, in comparison to the other low performing reference group that is yet adopting the shareholder profit maximization paradigm. This is manifested in their relationships with all stakeholders employees, customers, the civil society, and their shareholders - that they readily report to the public. They also have distinct governance standards which involve the Board of Directors and link executive compensation to ethical objectives.

Since banks play a significant role in society, they need a value system that is congruent with that of the society at large. Social self-regulation at the banking level can enforce better conduct and promote social change in desirable directions, since those responsible for enforcement would have greater power and authority, better access to information and easier interpretation of violated rules. Thus, the time is apt for Egyptian banks to adopt the stakeholder model, since ethical banking has indeed shown that financial and societal results are maximized in ethically conscious banks. Figure 1 proposes an applicable framework that banks could adopt in order to develop an all-inclusive stakeholder responsible banking model.

The stakeholder approach will ensure that stakeholders are not marginalized, since all their needs are appropriately catered for. Further, by making their operations society-oriented, banks invariably align their activities and programmes with their value statement. This can help to close the gap between stakeholder expectations, regulatory requirements, and profitability by focusing on empowering people, promoting innovation, and improving efficiency which extends beyond mere compliance with regulations. By establishing such a mechanism as a selfregulation approach, maximum social outcomes will be achieved. 


\section{Stage I: Policy Goals}

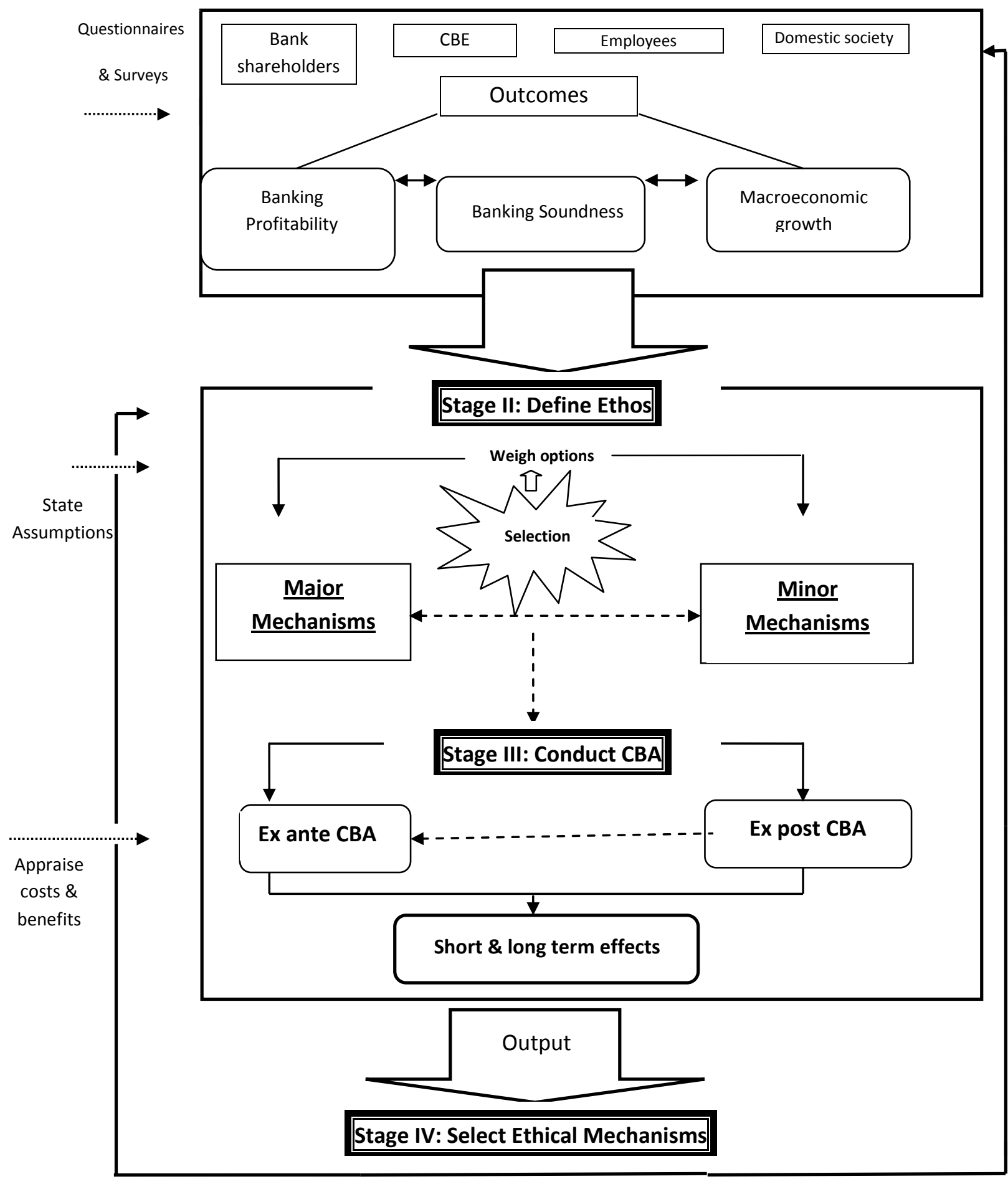

Figure 1: Design of Stakeholder Model 


\section{AUTHOR INFORMATION}

Nirmala Dorasamy, Durban University of Technology, South Africa. E-mail: nirmala@dut.ac.za (Corresponding author)

Monal Abdel-Baki, Durban University of Technology, South Africa. E-mail: monala@dut.ac.za

\section{REFERENCES}

1. Abdullah, F., Suhaimi, R., Saban, G., \& Hamali, J. (2011). Bank service quality (BSQ) index: An indicator of service performance. International Journal of Quality and Reliability Management, 28(5), 542-555.

2. Achua, J. K. (2008). Corporate social responsibility in Nigerian banking system. Society and Business Review, 3(1), 57-71.

3. $\quad$ Arcand, J. L., Berkes, E., \& Panizza, U. (2012). Too much finance? (IMF Working Papers, No. WP/12/161). Washington, D.C.: IMF.

4. Ayadi, R., Schmidt, R., Carbo, S., Arbak, E., \& Fernandez, F. (2009) Investigating diversity in the banking sector in Europe: The performance and role of savings banks. Brussels: Centre for European Policy Studies.

5. Barth, J. R., Caprio, G., \& Levine, R. (2004). Bank supervision and regulation: What works best? Journal of Financial Intermediation, 13, 205-48.

6. Beck, T., Degryse, H., \& Kneer, C. (2012). Is more finance better? Disentangling intermediation and size effects of financial systems. (European Banking Center Discussion Paper No. 2012-016).

7. Beck, T., Büyükkarabacak, B., Rioja, F., \& Valev, N. (2008). Who gets the credit? And does it matter? Household vs. firm lending across countries. (World Bank Policy Research Working Paper No. 4661).

8. Bini Smaghi, L. (2010). Has the financial sector grown too big? European Central Bank Nomura Seminar 'The Paradigm Shift after the Financial Crisis', Kyoto. Retrieved February 21, 2013 from www.ecb.int/press/key/date/2010/html/sp100415.en.html

9. Central Bank of Egypt (2013). Monthly statistical bulletin. January. Cairo: Central Bank of Egypt. Retrieved February 27, 2013 from http://www.cbe.org.eg/English/Economic+Research/Publications/ Monthly+Statistical+Bulletin/Jan+2013+Statistical+Bulletin.htm

10. Claessens, S., \& Laeven, L. (2005). Financial dependence, banking sector competition, and economic growth. Journal of the European Economic Association, 3, 179-207.

11. Cowton, C. (1998). The use of secondary data in business ethics research. Journal of Business Ethics, 17(4), 423-434.

12. Eccles, R. G., Ioannou, I., \& Serafeim, G. (2011). The impact of a corporate culture of sustainability on corporate behavior and performance. (Harvard Business School Working Papers No. 12-035). November 25.

13. El Ghoul, S., Guedhami, O., Kwok, C. C. Y., \& Mishra, D. R. (2011). Does corporate social responsibility affect the cost of capital? Journal of Banking and Finance, 35(9), 2388-2406.

14. Farook, S., Hassan, M. K., \& Lanis, R. (2011). Determinants of corporate social responsibility disclosure. Journal of Islamic Accounting and Business Research, 2(2), 114-141.

15. Freshfields Bruckhaus Deringer (2005). A legal framework for the integration of environmental, social and governance issues into institutional investment: A report produced for the asset management working group of the UNEP FI. Retrieved February 21, 2013 from http://www.unepfi,org/fileadmin/documents/ freshfields_legal_resp_20051123.pdf

16. Green, C. F. (1989). Business ethics in banking. Journal of Business Ethics, 8(8), 631-634.

17. Hogan, W. P., \& Sharpe, I. (1989). Prudential regulation of bank ownership and control. Economic Analysis and Policy, 19(1), 73-89.

18. Hong, H., \& Kacperczyk, M. (2009). The price of sin: The effects of norms on social markets. Journal of Financial Economics, 93(1), 15-36.

19. Hu, V., \& Scholtens, B. (2012). Corporate Social responsibility policies of commercial banks in developing countries. Sustainable Development. doi: 10.1002/sd.1551

20. Institute of International Finance (2011). The cumulative impact on the global economy of changes in the financial regulatory framework. Washington, D.C.: IIF. 
21. Jacques, K., \& Nigro, P. (1997). Risk-based capital, portfolio risk, and bank capital: A simultaneous equations approach. Journal of Economics and Business, 49, 533-47.

22. Jamali, D. (2007). The case for strategic corporate social responsibility in developing countries. Business and Society Review, 112(1), 1-27.

23. Jemli, R., \& Chtourou, N. (2010). Insurability challenges under uncertainty: An attempt to use the artificial neural network for the prediction of losses from natural disasters. Panoeconomicus, 1, 43-60.

24. Jones, D. (2000). Emerging problems with the basel capital accord: Regulatory capital arbitrage and related issues. Journal of Banking and Finance, 24(1-2), 35-58.

25. Kurtz, L., \& diBartolomeo, D. (2011). The long-term performance of a social investment universe. The Journal of Investing, 20(3), 95-102.

26. Le Maux, J., \& Le Saout, E. (2004). The performance of sustainability indexes. Finance India, 18, 737750 .

27. Lynch, J. J. (1991). Ethical bank: Surviving in an age of default. London: Macmillan.

28. McDonald, L. M., \& Rundle-Thiele, S. (2008). Corporate social responsibility and bank customer satisfaction: A research agenda. International Journal of Bank Marketing, 26(3), 170-182.

29. McWilliams, A., Siegel, D. S., \& Wright, P. M. (2006). Corporate social responsibility: Strategic implications. Journal of Management Studies, 43(1), 1-18.

30. Nagy, Z., Cogan, D., \& Sinnreich, D. (2013). Optimizing environmental, social, and governance factors in portfolio construction: An analysis of three ESG-tilted strategies. MSCI Research Insight. February.

Retrieved March 25, 2013 from http://www.msci.com/resources/research/articles/2013/MSCI\%20ESG\%20 Research\%20Insight_Optimizing\%20ESG\%20Factors\%20in\%20Portfolio\%20Construction \%20February\% 202013.pdf

31. Nkwankwu, G. O. (1991). Bank management: Principles and practice. Lagos: Malthouse Press Ltd.

32. Pomering, A., \& Donicar, S. (2006). Customers' Sensitivity to different measures of corporate social responsibility in the Australian banking sector. Australia and New Zealand Marketing Academy Conference (ANZMAC), Brisbane, December 4-6.

33. Rahaman, A. S., Lawrence, S., \& Roper, J. (2004). Social and environmental reporting at the VRA: Institutional legitimacy or legitimation crisis? Critical Perspectives on Accounting, 15(1), 35-56.

34. San-Jose, L., Retolaza, J. L., \& Gutierrez-Goiria, J. (2011). Are ethical banks different? A comparative analysis using the radical affinity index. Journal of Business Ethics, 100(1), 151-173.

35. San-Jose, L., \& Retolaza, J. L. (2008). Information transparency as a differentiation factor of ethical banking in Europe: A radical affinity index approach. The IUP Journal of Bank Management, 7(3), 7-22.

36. Schoenmaker, D., \& Werkhoven, D. (2012). What is the appropriate size of the banking system? (Duisenberg School of Finance Policy Paper Series, No. 28). October.

37. Shrieves, R. E., \& Dahl, D. (1992). The relationship between risk and capital in commercial banks. Journal of Banking and Finance, 16, 439-57.

38. Sigurthorsson, D. (2012). The Icelandic banking crisis: A reason to rethink CSR? Journal of Business Ethics, 111, 147-156.

39. Stiglitz, J. E. (2003). Globalization and its discontents. New York, N.Y.: W.W. Norton \& Co.

40. Tantawi, P., \& Youssef, A. (2012). The Importance of corporate social performance in place branding of retail banks in Egypt. African Journal of Economic and Management Studies, 3, 77-94.

41. The World Bank (2013). Market capitalization of listed companies (\% of GDP). World Bank Database. Retrieved March 25, 2013 from http://data.worldbank.org/indicator/CM.MKT.LCAP.GD.ZS

42. Tse, T. (2011). Shareholder and stakeholder theory: After the financial crisis. Qualitative Research in Financial Markets, 3(1), 51-63.

43. von Mettenheim, K., \& Butzbach, O. (2012). Alternative banking: Theory and evidence from Europe. Brazilian Journal of Political Economy, 32(4), 580-596.

44. Wahba, H. (2008). Exploring the moderating effect of financial performance on the relationship between corporate environmental responsibility and institutional investors: Some Egyptian evidence. Corporate Social Responsibility and Environmental Management, 15, 361-371.

45. Westlake, M. (2013). EU clinches Basel III deal on bank regulatory reform. Global Risk Regulator, 11(3).

46. Whitehead, C. K. (2012). The Goldilocks approach: Financial risk and staged regulation. Cornell Law Review, 97(5), 1267-1308. 
47. World Savings Banks Institute (2011). Corporate governance and access to finance. WSBI Perspectives, 62(March).

48. ----- (2010). Financial inclusion: How do we make it happen? (WSBI Position Papers, DOC 1169/10 (Vers. 1.0.)). 